\title{
CMEARTICLE
}

\section{Approach to falls among the elderly in the community}

\author{
Guat Cheng Ang ${ }^{1}$, MB Bch BAO, MRCP, Shou Lin $\underline{L o w}^{1}$, MRCP, MMed, Choon How $\underline{H o w}^{2,3}$, MMed, FCFP
}

Roger brought his 68-year-old mother, Amber, to your clinic for a consultation, as he was concerned that she was becoming more withdrawn and isolated. You have been their family doctor for the last decade. Amber opened up to share that she has been fearful of falling since her bad fall six months ago in the shower. She had restricted her own activities and made up excuses to avoid leaving her home even when family and friends invited her to join them.

\section{WHAT IS AN UNINTENTIONAL FALL AND A LONG LIE?}

An unintentional fall is an event that results in a person inadvertently coming to rest on the ground or at a lower level from causes other than sustaining a violent blow, loss of consciousness or sudden onset of paralysis as may occur during a stroke or epileptic seizure. ${ }^{(1)}$

A long lie is defined as an inability to get up from a fallen position, usually on the floor or ground, for more than an hour. It is associated with complications such as rhabdomyolysis, fear of falling, pneumonia, pressure sores and dehydration. ${ }^{(2)}$ Long lie is a marker of weakness, illness and isolation, and is associated with higher mortality rates. ${ }^{(3)}$ Only $50 \%$ of fallers are able to get up from the ground or floor after a fall. ${ }^{(4)}$

\section{WHAT HAPPENS TO FALLERS?}

A fall that is not addressed may lead to recurrent falls. ${ }^{(5)} 30 \%$ of fallers will fall again. Recurrent falls are defined as more than two falls in a year and are rarely attributable to a 'mechanical' (i.e. accidental) cause. The elderly usually fall due to a medical problem or risk factors that are modifiable. Falls are associated with a fear of falling. Fear of falling can happen even with a nearfall experience and is associated with self-inflicted reduction in activity or function, anxiety and even depression. This is also known as post-fall anxiety syndrome and is more common in older persons living alone, those with cognitive and mobility impairments, poor balance and history of falls. It is a risk factor for further falls. ${ }^{(6)}$

The most common modifiable risk factors for falls are poor balance and gait, medications (e.g. sedatives and antipsychotics), weakness (associated with medical conditions such as Parkinson's and stroke disease), joint disorders (e.g. osteoarthritis of the knees), impaired cognition resulting in poor safety awareness, poor vision (commonly from cataracts), environmental causes and inappropriate footwear. Recurrent falls are usually due to multiple factors. ${ }^{(7,8)}$

Falls due to syncope need to be assessed separately, as many studies consider falls and syncopal falls to be two separate diagnoses with two separate aetiologies. ${ }^{(9)}$ Common causes for syncopal falls include cardiac arrhythmias, neurally mediated syncope, orthostatic hypotension and carotid sinus syndrome. ${ }^{(10)}$

\section{HOW COMMON IS THIS IN MY PRACTICE?}

One in every three community-dwelling elderly persons aged 65 years and above have at least one fall within a year. ${ }^{(11)}$ The ratio increases to one in every two for those above 80 years of age. ${ }^{(12)}$ Episodes of falls are often accepted as part of ageing by both the patient and family members. Many elderly are 'silent fallers' who do not report the fall and fail to seek medical assistance unless injured. In Singapore, falls are a leading cause of injury among older adults. According to the National Registry of Diseases Office, Singapore, the crude incidence rate of unintentional falls in 2012 was 277.7 per 100,000 for adults aged 60 years and older. ${ }^{(13)}$ Falls account for $40 \%$ of injury-related deaths. ${ }^{(14)}$ The elderly population is increasing exponentially, and one in three individuals will be above 65 years of age by 2020. ${ }^{(15)}$ Hence, the number of fallers and 'silent fallers' will only increase in Singapore.

Falls can lead to serious consequences such as fractures, head injuries, reduced mobility, premature long-term care admissions and even death. In Singapore, falls account for $85 \%$ of all cases of elderly patients with trauma seen at the emergency department, according to the SAFE (Steps to Avoid Falls in the Elderly) study. ${ }^{(16)}$ Although most falls do not result in significant injury, the psychological effect of the fear of falling may cause anxiety, self-imposed activity restriction, social isolation, depression, and other negative effects on well-being and quality of life. If not properly addressed, the cycle of falls may set in (Fig. 1). An undetected fear of falling significantly impacts a patient's life. ${ }^{(17)}$

\section{HOW RELEVANT IS THIS TO MY PRACTICE?}

Primary care practitioners are often the first point of contact for many patients. With an ageing population, a greater proportion of elderly will be managed in the primary healthcare setting, presenting physicians with the opportunity to identify, assess and intervene for falls prevention.

${ }^{1}$ Department of Geriatric Medicine, ${ }^{2}$ Care and Health Integration, Changi General Hospital, ${ }^{3}$ Family Medicine Academic Clinical Programme, SingHealth Duke-NUS Academic Medical Centre, Singapore

Correspondence: Dr Ang Guat Cheng, Department of Geriatric Medicine, Changi General Hospital, 2 Simei Street 3, Singapore 529889. ang.guat.cheng@singhealth.com.sg 


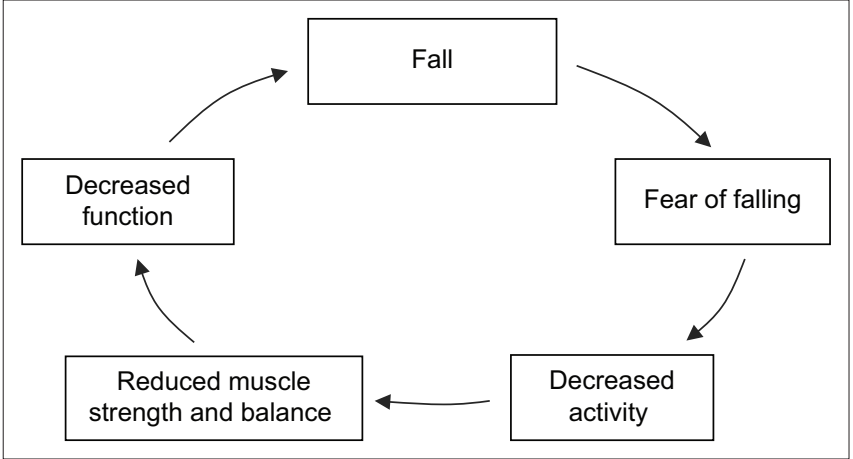

Fig. 1 Chart shows the cycle of falls.

'Silent fallers' will usually brush off incidents of falls as part and parcel of ageing, but they may visit a primary care practitioner for pain or injury related to a fall. A scrape on the knee or a bruise on the elbow can be an opening to screen for falls. As many patients do not volunteer information on falls, all older persons above 65 years should be screened for a fall or problems with gait and balance. Failure to adequately address a previous fall can result in a $30 \%$ increased chance of the individual falling again. ${ }^{(18)}$ Therefore, adopting a proactive approach to ask about falls, near falls and fear of falling can help us to identify and mitigate any modifiable risks before the next fall.

A fall assessment should be integrated into annual reviews for older patients who are on long-term follow-up in primary care for their chronic medical conditions.

\section{WHAT CAN I DO IN MY PRACTICE?}

During history taking, ask about a history of previous falls as it is an independent predictor of future falls. The fall event can be described in more detail by using the SPLATT mnemonic ${ }^{(19)}$ (Box 1). Taking a comprehensive history can help to identify the risk factors for falls.

A focused history includes: (a) pre fall (activity the patient was doing before the fall, any other symptoms prior to falling); (b) during the fall (what happened during the fall, how the patient landed); and (c) post fall (any post-fall syncope, drowsiness or long lie of more than an hour).

Next, do a medication review. Identify precipitating (e.g. acute medical problems) and predisposing factors, consisting of extrinsic causes (e.g. environment, footwear) and intrinsic causes (e.g. poor vision, poor balance and gait due to stroke/ Parkinsonism/joint abnormalities, poor cognition). Assess for complications from the fall such as fractures, head injury, skin lacerations, long lie complications, fear of falling. ${ }^{(2,8)}$

In the physical examination, pay particular attention to the patient's (a) gait and balance; (b) visual acuity (may want to also consider visual field assessment because conditions such as glaucoma and macular degeneration can adversely affect visual fields and result in an increased risk of falls as well); (c) neurological and cardiovascular systems; (d) postural blood pressure; and (e) screen for any injuries sustained.

Postural or orthostatic hypotension is diagnosed when, within 2-5 minutes of quiet standing (after a five-minute period of supine rest), one or both of the following is present: $\geq 20 \mathrm{mmHg}$

\section{Box 1. The SPLATT mnemonic: ${ }^{(19)}$}

Symptoms Symptoms before the fall, e.g. lightheadedness, palpitations

Previous Whether they had previous falls

Location Location of fall

Activity Activities they were doing before the fall

Time Time of the fall

Trauma Trauma (physical, psychological) associated with the fall

Box 2. Useful tips for a consultation with a patient after a fall:

- Get collaborative history from a witness of the fall.

- If the falls are unexplained, a syncopal fall will need to be excluded.

- Treat the modifiable risk factors for falls that have been identified.

- Early intervention includes referral for exercise and osteoporosis treatment.

- Consider
(a) reducing risk of falls;
(b) reducing frequency of falls; and
(c) minimising injuries during and after falls

drop in systolic pressure and/or $\geq 10 \mathrm{mmHg}$ drop in diastolic pressure. The heart rate normally rises immediately on standing. Investigations to be undertaken include basic blood tests to screen for precipitating causes of falls, such as full blood count, renal panel, C-reactive protein, calcium and vitamin D level for bone health screening; and electrocardiography (if suspicious of a syncopal/cardiac cause for the fall). ${ }^{(20-23)}$ Useful tips for the consultation are shown in Box 2.

\section{Interventions}

There is good research evidence that a number of single interventions can reduce falls and injuries. These interventions can be in the clinic or home setting and target the risk factors shown in Tables I and II.

Targeted multifactorial interventions based on falls risk assessments have been shown to be effective, particularly in the high-risk falls group and those with a previous history of falls. ${ }^{(25)}$ A common pitfall for falls assessment is the failure to address bone health. The Osteoporosis Self-assessment Tool for Asians is a simple tool to screen for osteoporosis. ${ }^{(26)}$

Falls are preventable and the risk of injurious falls can be reduced if risk factors are identified early and there is timely introduction of appropriate interventions.

\section{WHEN SHOULD I REFER TO A SPECIALIST?}

If there is clear history of a loss of consciousness, a workup for possible causes of syncope needs to be carried out. Diagnoses of carotid sinus hypersensitivity and tachyarrhythmias/ bradyarrhythmias also need to be considered. Implantation of a permanent pacemaker may be beneficial for this group of patients. For patients with recurrent falls, a referral to a falls clinic at a hospital would allow a multidisciplinary assessment and a tailored multicomponent intervention to be performed to target pertinent risk factors. 
Table I. Risk factors and possible interventions in the clinic setting.

\begin{tabular}{|c|c|c|}
\hline Risk factor & Theory & Intervention \\
\hline Vision & $\begin{array}{l}\text { Reduced visual acuity, poor contrast } \\
\text { sensitivity and decreased visual fields makes } \\
\text { spotting hazards, obstacles and navigating } \\
\text { uneven ground difficult. Foot placement } \\
\text { might be impaired when walking on uneven } \\
\text { ground. }\end{array}$ & $\begin{array}{l}\text { - Ask about their vision and screen for correctable visual } \\
\text { abnormalities e.g. cataracts. The first cataract surgery is proven to } \\
\text { reduce falls. }{ }^{(24)} \\
\text { - Advise against the use of multifocal lenses for individuals who are } \\
\text { active outdoors. }\end{array}$ \\
\hline Medication review & $\begin{array}{l}\text { Psychotrophic medications (e.g. sedatives, } \\
\text { antidepressants and antipsychotics) } \\
\text { increase fall risks. }\end{array}$ & $\begin{array}{l}\text { - Medication review should be carried out to ascertain if there is } \\
\text { a need to continue. If yes, it should be adjusted to the lowest } \\
\text { effective dose. } \\
\text { - Medication side effects should be communicated to the patient. }\end{array}$ \\
\hline $\begin{array}{l}\text { Postural } \\
\text { hypotension }\end{array}$ & $\begin{array}{l}\text { Postural hypotension on standing increases } \\
\text { the risk for falls. It is commonly caused by } \\
\text { dehydration, the use of medications such as } \\
\text { diuretics or antihypertensive medications } \\
\text { and autonomic neuropathy. }\end{array}$ & $\begin{array}{l}\text { - Besides a medication review, ensure that the patient is adequately } \\
\text { hydrated. } \\
\text { - Exercise and physical activity will improve postural hypotension } \\
\text { secondary to inactivity and deconditioning. Compression stockings } \\
\text { may be effective in some cases. } \\
\text { - If postural hypotension persists, medications such as } \\
\text { fludrocortisone/midodrine may be prescribed. }\end{array}$ \\
\hline $\begin{array}{l}\text { Vitamin D } \\
\text { supplementation }\end{array}$ & $\begin{array}{l}\text { The AGS/BGS guidelines recommend } \\
\text { vitamin D supplementation of at least } 800 \\
\text { IU per day for older persons at risk for falls. }\end{array}$ & $\begin{array}{l}\text { Community-dwelling elderly and those in long-term facilities with } \\
\text { deficiency should have their vitamin D repleted. }\end{array}$ \\
\hline Education & $\begin{array}{l}\text { Education is essential in empowering } \\
\text { patients to reduce the incidence of falls. }\end{array}$ & $\begin{array}{l}\text { - Individual risk factors that were identified and strategies to minimise } \\
\text { falls risk should be shared with the patient and caregivers. } \\
\text { - Fear of falling should be addressed with the patient and loved ones } \\
\text { to empower ambulation. }\end{array}$ \\
\hline
\end{tabular}

AGS/BGS: American Geriatrics Society/British Geriatrics Society

Table II. Risk factors and possible interventions in the home setting.

\begin{tabular}{|c|c|c|}
\hline Risk factor & Theory & Intervention \\
\hline Exercise & $\begin{array}{l}\text { Exercising for at least } 180 \text { minutes per week, } \\
\text { with an emphasis on balance, strength and } \\
\text { gait training, is effective in falls prevention. }\end{array}$ & $\begin{array}{l}\text { - Group exercise or home exercise needs to be tailored to the } \\
\text { person's physical capability. } \\
\text { - A referral to a physiotherapist can be made for more individualised } \\
\text { therapy, targeting specific risk factors. Where appropriate, such } \\
\text { exercises should be supervised. }\end{array}$ \\
\hline $\begin{array}{l}\text { Home } \\
\text { environment }\end{array}$ & $\begin{array}{l}\text { Hazards such as poor lighting, loose rugs, lack } \\
\text { of grab bars and slippery floors are common } \\
\text { contributing factors to falls at home. Home } \\
\text { safety interventions are recommended for } \\
\text { those who have fallen. Some elderly people } \\
\text { will benefit from the use of a walking aid, } \\
\text { such as a walking frame or stick. }\end{array}$ & $\begin{array}{l}\text { - Refer to an occupational therapist for home safety assessment and } \\
\text { advice on modifications. } \\
\text { - Home modifications can be done via the HDB EASE programme. } \\
\text { - A physiotherapist can assess the need for a suitable walking aid, and } \\
\text { the Seniors' Mobility and Enabling Fund may be utilised to purchase } \\
\text { appropriate equipment for those with financial constraints. }\end{array}$ \\
\hline Footwear & $\begin{array}{l}\text { The shape of our feet changes as we age. } \\
\text { Bunions, thick nails and poorly fitted } \\
\text { footwear with resultant abrasion and } \\
\text { blisters cause pain and discomfort. }\end{array}$ & $\begin{array}{l}\text { - Inspect the patient's footwear. Proper footwear has a low, broad } \\
\text { heel and a firm heel counter for improved stability when walking, } \\
\text { slip-resistant soles for better grip, and fastenings to keep the foot } \\
\text { anchored in the shoe (Fig. 2). } \\
\text { - Avoid bedroom slippers/socks. }\end{array}$ \\
\hline
\end{tabular}

HDB EASE: Housing and Development Board Enhancement for Active Seniors

\section{USEFUL LINKS}

- Housing and Development Board's Enhancement for Active Seniors programme:

https://www.hdb.gov.sg/cs/infoweb/residential/living-in-anhdb-flat/for-our-seniors/ease (accessed January 1, 2020)

- Prevention of Falls Network Earth: http://profane.co (accessed June 1, 2019)

- Changi General Hospital's No Falls Programme: https://www.cgh.com.sg/nofalls/ (accessed January 1, 2020)
- $\quad$ Fall prevention exercises (accessed January 1, 2020)

- Introduction: https://vimeo.com/48017706

- Strengthening: https://vimeo.com/48014858

- Balancing: https://vimeo.com/48014859

- Cool down/conclude: https://vimeo.com/48016508

- $\quad$ Fall recovery (accessed January 1, 2020)

- What to do after a fall (alone): https://vimeo.com/47986154

- What to do after a fall with help from someone: https://vimeo.com/47987342 


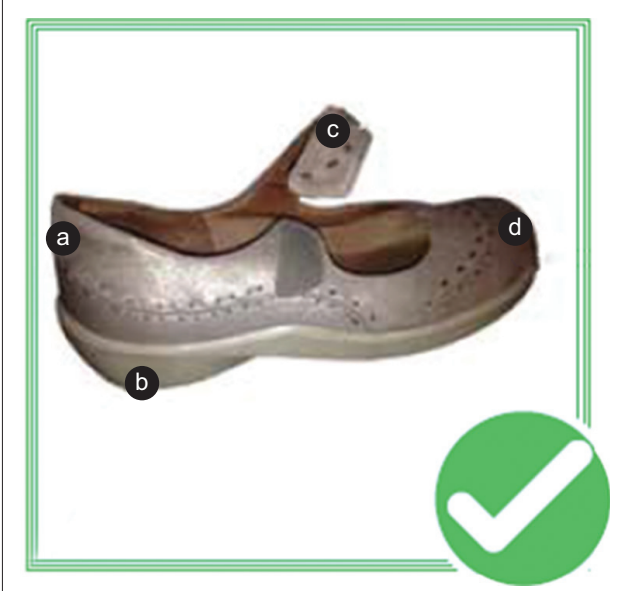

(a) Firm heel counter with a rounded edge.

(b) A low, broad, slip-resistant heel to maximise contact with the ground.

(c) Velcro, buckle or laces to hold the foot firmly in place.

(d) The front of the shoe, known as the toe box should be deep enough and wide enough to accommodate toes comfortably, but not too loose.

Fig. 2 Diagram shows the components of proper footwear to reduce the chance of falls.

\section{TAKE HOME MESSAGES}

1. Falls and 'silent falls' are common and under-recognised in our community.

2. Falls with risk factors that are not addressed will lead to recurrent falls and poor quality of life.

3. Falls and near falls can result in fear of falling, post-fall anxiety syndrome, depression and reduction in activities, with a negative impact on general well-being.

4. Modifiable risks include poor vision, balance, poor gait, motor weakness, joint disorders, psychotropic drugs, sedatives, anti-hypertension medications, choice of footwear and environment factors.

5. Timely referrals for cataract operations, balance and strengthening exercises, and osteoporosis treatment can reduce the risk of falls and injurious outcomes.

You reviewed Amber six months after her son brought her to you. She walked in by herself this time and reported that she had regained her confidence and independence after the cataract surgery you had referred her for. Earlier, she had also heeded your advice to stop wearing her fluffy bedroom slippers, which could have caused her falls. You noted no side effects from her biphosphonates and reminded her to be careful, as she had started taking the bus again to visit her grandchildren.
ABSTRACT One in three community-dwelling elderly aged $\geq 65$ years and one in two aged $>80$ years will have at least one fall within a year. Many elderly people are 'silent fallers' who do not report the fall nor seek medical assistance unless they are injured. In Singapore, falls account for $40 \%$ of injury-related deaths. Unaddressed risk factors for falls lead to recurrent falls and poor quality of life. Elderly people who have experienced falls and near falls can have a fear of falling, post-fall anxiety syndrome, depression and reduction in activities, with a negative impact on their well-being. Primary care doctors can screen and optimise modifiable risk factors such as poor vision, balance, poor gait, motor weakness, joint disorders, psychotropic drugs, sedatives, anti-hypertension medications, choice of footwear and environment factors. Timely referrals for cataract operations, balance and strengthening exercises, and osteoporosis treatment can reduce the risk of falls and injurious outcomes.

Keywords: community, elderly, falls, prevention

\section{REFERENCES}

1. The prevention of falls in later life. A report of the Kellogg International Work Group on the Prevention of Falls by the Elderly. Dan Med Bull 1987; 34(Suppl 4): $1-24$.

2. Lord SR, Sherrington C, Hylton BM. Falls in older people. Risk factors and strategies for prevention. 1st ed. Cambridge: Cambridge University Press, 2001: 10-11.

3. Tinetti M, Inouye S, Gill TM, Doucette JT. Shared risk factors for falls, incontinence, and functional dependence. Unifying the approach to geriatric syndromes. JAMA 1995; 273:1348-53.

4. Tinetti ME, Liu WL, Claus EB. Predictors and prognosis of inability to get up after falls among elderly persons. JAMA 1993; 269:65-70.

5. Evans JG. Fallers, non-fallers and Poisson. Age Ageing 1990; 19:268-9.

6. Murphy SL, Dubin JA, Gill TM. The development of fear of falling among community-living older women: predisposing factors and subsequent fall events. J Gerontol A Biol Sci Med Sci 2003; 58:M943-7.

7. Tideiksaar R. Preventing falls: how to identify risk factors, reduce complications. Geriatrics 1996; 51:43-6, 49-50, 53, quiz 54-5.

8. Rao SS. Prevention of falls in older patients. Am Fam Physician 2005; 72:81-8.

9. Shaw FE, Kenny RA. The overlap between syncope and falls in the elderly. Postgrad Med J 1997; 73:635-9.

10. Kapoor W, Snustad D, Peterson J, et al. Syncope in the elderly. Am J Med 1986; 80:419-28.

11. Guideline for the prevention of falls in older persons. American Geriatrics Society, British Geriatrics Society, and American Academy of Orthopaedic Surgeons Panel on Falls Prevention. J Am Geriatr Soc 2001; 49:664-72.

12. O'Loughlin JL, Robitaille Y, Boivin JF, Suissa S. Incidence of and risk factors for falls and injurious falls among the community-dwelling elderly. Am J Epidemiol 1993; 137:342-54.

13. Health Promotion Board. Falls Prevention Among Older Adults Living in the Community. HPB-MOH Clinical Practice Guidelines 1/2015 [online]. Available at: https://www.hpb.gov.sg/docs/default-source/pdf/cpg_falls_preventionb274. pdf. Accessed September 1, 2019.

14. Australian and New Zealand Falls Prevention Society. Info about falls. Injuries from falls. Available at: https://www.anzfallsprevention.org/info. Accessed January 1, 2020.

15. Department of Statistics Singapore. Population trends 2019. Understanding old-age support ratio. Available at: https://www.singstat.gov.sg/modules/ infographics/old-age-support-ratio. Accessed September 1, 2019.

16. Matchar DB, Duncan PW, Lien CT, et al. Randomized controlled trial of screening, risk modification, and physical therapy to prevent falls among the elderly recently discharged from the emergency department to the community: the steps to avoid falls in the elderly study. Arch Phys Med Rehabil 2017; 98:1086-96.

17. Tinetti ME, Mendes de Leon CF, Doucette JT, Baker DI. Fear of falling and fallrelated efficacy in relationship to functioning among community-living elders. 
J Gerontol 1994; 49:M140-7.

18. Tinetti ME, Speechley M, Ginter SF. Risk factors for falls among elderly persons living in the community. N Engl J Med 1988; 319:1701-7.

19. Tideiksaar R. Falls in older persons: prevention and management. 2nd ed. Baltimore, MD: Health Professions Press, 1998.

20. Prevention of falls in older persons: AGS/BGS clinical practice guideline [online] Available at: https://www.archcare.org/sites/default/files/pdf/2010-preventionof-falls-in-older-persons-ags-and-bgs-clinical-practice-guideline.pdf. Accessed September 1, 2019.

21. King MB. Falls. In: Hazzard's Geriatric Medicine and Gerontology. 6th ed. New York: McGraw-Hill Education, 2009: 659-70.

22. Guideline for the prevention of falls in older persons. American Geriatrics
Society, British Geriatrics Society, and American Academy of Orthopaedic Surgeons Panel on Falls Prevention. J Am Geriatr Soc 2001; 49:664-72.

23. Moncada LVV, Mire LG. Preventing falls in older persons. Am Fam Physician 2017; 96:240-7.

24. Brannan S, Dewar S, Sen J, et al. A prospective study of the rate of falls before and after cataract surgery. Br J Ophthalmol 2003; 87:560-2.

25. Gillespie LD, Robertson MC, Gillespie WJ, et al. Interventions for preventing falls in older people living in the community. Cochrane Database Syst Rev 2012; (9):CD007146.

26. Koh LK, Sedrine WB, Torralba TP, et al; Osteoporosis Self-Assessment Tool for Asians (OSTA) Research Group. A simple tool to identify Asian women at increased risk of osteoporosis. Osteoporos Int 2001; 12:699-705. 


\section{SINGAPORE MEDICAL COUNCIL CATEGORY 3B CME PROGRAMME} (Code SMJ 202003A)

1. One in every 20 community-dwelling elderly aged 65 years and above will have at least one fall within a year.

2. Falls account for only $5 \%$ of injury-related deaths.

3. According to the SAFE (Steps to Avoid Falls in the Elderly) study conducted in Singapore, $85 \%$ of all cases of trauma in elderly patients seen at the emergency department are due to falls.

4. Falls can lead to serious consequences such as fractures, head injuries, reduced mobility, premature longterm care admissions and even death.

5. When falls do not result in significant injury for the elderly, residual fear of falling, self-imposed activity restriction, social isolation, depression and other negative effects on well-being and quality of life are minimal and insignificant.

6. If the cycle of falls sets in due to an undetected fear of falling, the patient's life can be significantly impacted.

7. Syncope and falls can be assessed together, as many studies consider them to share many similar aetiologies.

8. Causes of syncopal falls include cardiac arrhythmias, neurally mediated syncope, orthostatic hypotension and carotid sinus syndrome.

9. 'Silent fallers' brush off falls as part and parcel of ageing but may visit a primary practitioner for pain or injury related to a fall.

10. Failure to adequately address a previous fall can result in an approximately $8 \%$ increased chance of the individual falling again.

11. Physicians should ask older people about their history of previous falls, as it is an independent predictor of future falls risk.

12. The fall event can be elicited in a structured way using the SPLATT mnemonic (symptoms, previous fall, location, activity, time and trauma).

13. Predisposing factors that can increase the risk of falls include current medication intake, poor vision, poor cognition, balance and gait, postural hypotension, arrhythmias, and mechanical joint pain.

14. It is also important to review the patient's past medical history and long-term medications associated with contributing factors for falls and risk of severe injuries (e.g. osteoporosis).

15. Postural or orthostatic hypotension is diagnosed when, within 2-5 minutes of quiet standing (after a fiveminute period of supine rest), there is an at least $10 \mathrm{mmHg}$ drop in systolic pressure with a proportionate drop in diastolic pressure.

16. The goals of treatment should include treatment of injuries sustained and identifying risk factors for falls so that early intervention can be done to reduce the risk and frequency of falls as well as to minimise injuries during and after any future falls.

17. The first cataract surgery has been associated with a reduction in falls.

18. Possible interventions to reduce risk for future falls include screening and interventions for hydration status, exercise and physical activity; vitamin D supplementation; decluttering the home environment; choosing to avoid walking on uneven floors; and ensuring that footwear fits well.

19. Hazards such as poor lighting, loose rugs, lack of grab bars and slippery floors are common contributing factors to falls at home.

20. Useful community resources in Singapore include the Housing and Development Board's Enhancement for Active Seniors programme for home modifications, and the Senior Mobility and Enabling Fund for those with financial constraints to purchase needed equipment.

\section{Doctor's particulars:}

Name in full:

Specialty:

MCR no.:

Email:

\section{SUBMISSION INSTRUCTIONS}

Visit the SMJ website: http://www.smj.org.sg/current-issue and select the appropriate quiz. You will be redirected to the SMA login page.

For SMA member: 1) Log in with your username and password (if you do not know your password, please click on 'Forgot your password?'). (2) Select your answers for each quiz and click 'Submit'.

For non-SMA member: (1) Create an SMJ CME account, or log in with your SMJ CME username and password (for returning users). (2) Make payment of SGD 21.40 (inclusive of $7 \%$ GST) via PayPal to access this month's quizzes. (3) Select your answers for each quiz and click 'Submit'.

RESULTS:

(1) Answers will be published online in the SMJ May 2020 issue. (2) The MCR numbers of successful candidates will be posted online at the SMJ website by 11 May 2020 . (3) Passing mark is $60 \%$. No mark will be deducted for incorrect answers. (4) The SMJ editorial office will submit the list of successful candidates to the Singapore Medical Council. (5) One CME point is awarded for successful candidates. (6) SMC credits CME points according to the month of publication of the CME article (i.e. points awarded for a quiz published in the March 2020 issue will be credited for the month of March 2020, even if the deadline is in May 2020).

Deadline for submission (March 2020 SMJ 3B CME programme): 12 noon, 4 May 2020 